emulsions the lecithin is immediately taken up by the solvents. This action, which is best shown with ether, is related to the precipitating power of the salts, and it appears necessary to break up the emulsions before extraction is possible. Mercuric cyanide and boric acid do not precipitate the emulsions and after treatment with ether no lecithin is dissolved by the latter.

Certain non-electrolytes tested do not appreciably precipitate the emulsions, and their presence does not aid the solution by ether, but the addition of traces of salt solutions to the mixtures brings about an immediate solution of the lecithin, even when great excesses of the non-electrolytes are used. This behavior has certain practical applications.

Finally, attention is called to the peculiar behavior of bile salts.

NORTHWESTERN UNIVERSTTY MEDICAI.

SCHOOL, CHICAGo.

\title{
ON THE OCCURRENCE OF COPPER IN OYSTERS.
}

\author{
BY J. T. WILLARD. \\ Received March $19,1908$.
}

Last spring the attention of Dr. S. J. Crumbine, secretary of the Kansas State Board of Health, was called to some cases of illness following the use of fresh oysters in which these were suspected to be the cause. Two samples were sent to the writer for examination. They had a distinctly greenish blue color, and qualitative tests showed the presence of copper. The oysters also possessed a noticeable coppery taste. Quantitative determinations of the amount of copper were made. One of the samples was found to contain 0.0437 per cent. of copper, or 0.302 per cent. calculated on the dry substance; the other contained 0.0324 per cent., or 0.2 I I per cent. in the dry substance. As copper has been recognized as a constituent of many species of mollusks it seemed desirable to test other samples. 'Two other samples of fresh oysters and six samples of canned oysters, sold under the name of Cove Oysters, were examined and in every case copper was found to be present. As the oyster season was practically at an end at that tine, further investigation was postponed until October, when analyses were made of a considerable number of samples secured chiefly with reference to determination of water content. In all 34 distinct samples were analyzed. The results are shown in the following table.

With the exception of those marked as bulk samples these oysters were placed in glass jars as they were taken from the shells. In most cases the amount of liquor present was too small to determine the copper, but in other cases where the liquor was examined copper was found present, and in no instance was copper absent from the oysters although in sample No. I2,II the amount was very small. The uniformity of the 
TABLE Showtng COPper in Oysters.

\begin{tabular}{|c|c|c|c|c|c|c|c|}
\hline $\begin{array}{c}\text { Serial } \\
\text { number. }\end{array}$ & $\begin{array}{l}\text { Place of } \\
\text { purchase. }\end{array}$ & & Name. & Liquid. & Meat. & Sample. & $\begin{array}{c}\text { Dry } \\
\text { sample. }\end{array}$ \\
\hline 12,094 & Manhattan & & Bulk, "Booth's" & $\cdots$ & 0.0072 & 0.0072 & 0.087 \\
\hline 12,095 & " & & " " & 0.0056 & 0.0083 & 0.0072 & 0.079 \\
\hline I 2,096 & “ & & ، & 0.0016 & 0.0084 & $0 . \infty 07 \mathrm{I}$ & 0.079 \\
\hline 12,097 & " & & "، & $\ldots \ldots$ & $\ldots \ldots$ & 0.0062 & 0.059 \\
\hline 12,098 & Washington, & D.C. & Bulk, No. I & $\ldots \ldots$ & $\ldots \ldots$ & 0.0084 & 0.085 \\
\hline I 2,099 & " & “ & Bulk, No. 2 & $\ldots \ldots$ & $\ldots \ldots$ & 0.0022 & 0.023 \\
\hline I 2,100 & “ & $\because$ & Curryomian & 0.0048 & 0.0056 & 0.0052 & 0.055 \\
\hline 12 , IOI & 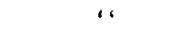 & $" r$ & Rockaway. & 0.0048 & 0.0060 & 0.0055 & 0.043 \\
\hline 12,102 & “ & "، & York River & 0.0024 & 0.0056 & 0.0042 & 0.034 \\
\hline 12,103 & $\because$ & ‘ & Hampton Bars & 0.0064 & 0.0056 & $0.006 \mathrm{I}$ & 0.0 .58 \\
\hline $12, \mathrm{IO}_{4}$ & $\because$ & “ & Cape Cod & 0.0048 & 0.0068 & $0.005^{8}$ & 0.040 \\
\hline 12,105 & $" r$ & “ & Blue Points & 0.0016 & 0.0064 & $0.004 \mathrm{I}$ & 0.029 \\
\hline I2, 106 & “ & “ & Coam River & $\ldots \ldots$ & $\ldots \ldots$ & 0.0058 & 0.044 \\
\hline 12,107 & “ & “ & Blue Points & $\ldots \ldots$ & $\ldots \ldots$ & 0.0044 & 0.034 \\
\hline 12,108 & “ & “ & Lynnhaven Bay & $\ldots \ldots$ & $\ldots \ldots$ & 0.0104 & 0.064 \\
\hline 12,109 & “ & “ & Rockaways & $\ldots \ldots$ & $\ldots \ldots$ & 0.0080 & 0.060 \\
\hline 12,110 & " & “ & Clarke River & $\ldots \ldots$ & $\ldots \ldots$ & 0.0008 & 0.006 \\
\hline I2, III & Philadelphia & & $\begin{array}{l}\text { Tucker Salts, Barne- } \\
\text { gat Bay }\end{array}$ & $\ldots \ldots$ & & 0.0076 & 0.052 \\
\hline $12, I I 2$ & ". & & $\begin{array}{l}\text { Rockaway, Partial } \\
\text { Salts }\end{array}$ & & & & 0.018 \\
\hline I 2, I I 3 & “ & & $\begin{array}{l}\text { Chituque Salts, Jer- } \\
\text { sey Coast }\end{array}$ & & & 0.0068 & 0.048 \\
\hline I 2, I I 4 & " & & $\begin{array}{c}\text { Maurice River Cove, } \\
\text { Baltimore Bay }\end{array}$ & $\ldots \ldots$ & $\ldots$ & 0.0008 & 0.006 \\
\hline 12, I 15 & "“ & & $\begin{array}{l}\text { Cedar Rock Salts, } \\
\text { Jersey Coast }\end{array}$ & $\ldots \ldots$ & $\ldots \ldots$ & 0.0016 & 0.012 \\
\hline 12,116 & “ & & $\begin{array}{l}\text { Maurice River Cove, } \\
\text { transplanted }\end{array}$ & & & 0.0048 & 0.032 \\
\hline 12,117 & New York & & Cape Cod & $\ldots \ldots$ & $\ldots \ldots$ & 0.0032 & 0.021 \\
\hline 12, I 8 & “ & & Lynnhaven, Va. & $\ldots \ldots$ & $\ldots \ldots$ & 0.0008 & 0.005 \\
\hline 12,119 & “ & & $\begin{array}{l}\text { Rockaways, Long } \\
\text { Island }\end{array}$ & $\ldots \ldots$ & & 0.0052 & 0.047 \\
\hline 12,120 & “ & & $\begin{array}{l}\text { Blue Points, Long } \\
\text { Island }\end{array}$ & & & $\infty 092$ & 0.071 \\
\hline I 2, I 2 I & “ & & Sea Puits & $\cdots \cdots$ & $\ldots \ldots$ & 0.0072 & $0.05 \mathrm{x}$ \\
\hline 12,122 & Baltimore & & Easton Bay, Md. & $\ldots \ldots$ & $\ldots \ldots$ & $0 . \infty 076$ & 0.087 \\
\hline 12,123 & " & & Lynnhaven & $\ldots \ldots$ & $\ldots \ldots$ & 0.0164 & 0.170 \\
\hline 12,124 & “ & & Chester River & $\ldots \ldots$ & $\ldots \ldots$ & 0.0084 & 0.110 \\
\hline 12,125 & $"$ & & Horn Harbor & $\ldots \ldots$ & $\ldots \ldots$ & 0.0028 & 0.025 \\
\hline 12,126 & " & & West River, Md. & $\ldots \ldots$ & $\ldots \ldots$ & $0 . \infty 4^{8}$ & 0.052 \\
\hline 12,127 & ، & & Swamp Point & $\ldots \ldots$ & $\ldots \ldots$ & 0.0028 & 0.038 \\
\hline
\end{tabular}

presence of copper warrants the conclusion that that metal is a normal constituent of oysters. The much larger amounts in the first ones examined should perhaps be regarded as abnormal and may have been due to special conditions, the nature of which is unknown. It is not 
improbable that, especially with susceptible individuals, those oysters containing the larger quantities of copper might be a cause of illness.

In respect to the mode of amalysis, it nay be of interest to state that in most cases the orsters were digested with a ninimum of sulphuric acid, as in the Kjeldahl method for the determination of nitrogen, the cleat solution was diluted and the copper deposited electrolytically. Check tests of the reagents proved them to be free from copper.

KANSAS STATE AGRICULTURAL COI,REG.

MANHATTAN, KANS.

\section{NOTES.}

Notes on Mr. Keen's Paper' on the Volumetric Determination of Zinc. Mr. Keen disarms criticism by disclaiming any great originality for the method he describes. Unfortunately he has not selected the best of the old methods, and some of the things he advises are likely to cause trouble.

The methods given for preparing the ferrocyanide solution and for the titration are the very excellent ones described by Dr. Low.

The method given for standardizing is complicated and unreliable. A much simpler one is to partly dissolve a single large piece of high-grade spelter in dilute hydrochloric acid, dilute the solution so that it will contain about 5 grams of zine per liter and determine the zinc by any reliable gravimetric method. I prefer to determine the zinc as pyrophosphate, as the method is simpler than most, and I have found it extremely accurate. If not more than three-quarters of the piece of spelter is dissolved the solution will contain nothing but zinc, and consequently needs no purification. Two or three liters can be made up at once and used as a standard for nany months. If extreme accuracy is required, the zinc should be determined in weighed portions of the solution and weighed amounts be used for standardizing.

In the standardizing and actual analysis the rolume of the solution, temperature, amount of free acid and of ammonium chloride. the indicator and the method of using it should be kept within very narrow linits or the results will be unreliable. The effect of ammonium chloride on the amount of ferrocyanide necessary is usually neglected but it is quite important.

Sampling Spelter.- The method proposed is very unreliable and likely to cause errors. It has been condenned by the International Committee at the Congress of Applied Chemistry at Rome. The method they recommend is by far the best, $i$. e., to saw the slabs and use the sawdust for a sample. It is best to saw each slab entirely in two, it must at least be cut to the middle each tince. An ordinary band saw, such as is used

1 This Journal, 30, 225. 